\title{
Co-option and evolution of non-olfactory proteinaceous pheromones in a terrestrial lungless salamander
} Kari A. Doty ${ }^{1}$, Damien B. Wilburn ${ }^{1,2^{*}}$, Kathleen E. Bowen ${ }^{1}$, Pamela W. Feldhoff ${ }^{1}$, and Richard C. Feldhoff ${ }^{1}$

${ }^{1}$ Department of Biochemistry and Molecular Biology, University of Louisville, Louisville, KY

${ }^{2}$ Department of Genome Sciences, University of Washington, Seattle, WA

*Corresponding author, email: dwilburn@u.washington.edu

Keywords: pheromones; reproduction; salamander; sexual selection; proteomics

\begin{abstract}
Gene co-option is a major force in the evolution of novel biological functions. In plethodontid salamanders, males deliver proteinaceous courtship pheromones to the female olfactory system or transdermally to the bloodstream. Molecular studies identified three families of highly duplicated, rapidly evolving pheromones (PRF, PMF, and SPF). Analyses for Plethodon salamanders revealed pheromone mixtures of primarily PRF and PMF. The current study demonstrates that in Desmognathus ocoee - a plesiomorphic species with transdermal delivery - SPF is the major pheromone component representing $>30 \%$ of total protein. Chromatographic profiles of $D$. ocoee pheromones were consistent from May through October. LC/MS-MS analysis suggested uniform SPF isoform expression between individual male $D$. ocoee. A gene ancestry for SPF with the Three-Finger Protein superfamily was supported by intron-exon boundaries, but not by the disulfide bonding pattern. Further analysis of the pheromone mixture revealed paralogs to peptide hormones that contained mutations in receptor binding regions, such that these novel molecules may alter female physiology by acting as hormone agonists/antagonists. Cumulatively, gene co-option, duplication and neofunctionalization have permitted recruitment of additional gene families for pheromone
\end{abstract}


activity. Such independent co-option events may be playing a key role in salamander speciation by altering male traits that influence reproductive success.

\section{Introduction}

Novel phenotypes are rarely thought to evolve through de novo synthesis, but more commonly through the co-option of extant structures that can be repurposed for new functions $[1,2]$. At the genomic level, gene co-option can occur through multiple mechanisms, with the most common route being gene duplication followed by mutation accumulation that can drive neofunctionalization $[3,4]$. Genes that are co-opted for new functions typically possess characteristics that already make them well-suited for their new roles: for example, $\alpha$-crystallins in the lens of the eye form transparent arrays that refract light and focus it on the retina. These liquid crystal arrays require that the proteins remain stable at very high concentrations, a quality of the heat shock protein family from which $\alpha$-crystallins were co-opted $[5,6]$. While innovation and co-option through natural selection have been widely studied in many systems [7-10], it has been minimally examined in the context of sexual selection.

For more than 100 million years, plethodontid salamanders have utilized a system of nonvolatile proteinaceous courtship pheromones that regulate female mating receptivity and behavior $[11,12]$. Part of the courtship ritual includes a highly specialized behavior (tail straddling walk, TSW) that coordinates and facilitates sperm transfer from males to females. Preceding the annual courtship season, plasma androgens rise in male salamanders and induce development of a submandibular mental gland dedicated to the synthesis of non-volatile proteinaceous courtship pheromones which reduce the length of TSW[12]. In the red-legged salamander (Plethodon shermani) and other closely related species, a male salamander delivers 
pheromones by "slapping" the mental gland to the female's snout, where pheromones diffuse into the female olfactory chamber, bind to receptors on vomeronasal neurons, and activate regions of the brain involved in mating behavior $[13,14]$. This olfactory form of pheromone perception closely resembles that of most other animals [15]; however, only 27 out of $\sim 355$ plethodontid species utilize this form of delivery. The majority of plethodontid species ( $\sim 300$ spp.) apply pheromones transdermally by "scratching" a female's dorsum using enlarged premaxillary teeth [16]. Subsequent rubbing of the mental gland over the abraded site presumably allows pheromones to diffuse into the bloodstream [17]. These pheromones do not activate neurons in the vomeronasal organ [18], and must influence female physiology and behavior through alternative, but currently unknown, pathways.

Three major plethodontid pheromones have been biochemically purified and assayed for behavioral effects: Plethodontid Receptivity Factor (PRF) and Plethodontid Modulating Factor (PMF) in P. shermani, and Sodefrin Precursor-like Protein (SPF) in Desmognathes ocoee. All three proteins persist within the mental gland as multi-isoform blends, and when delivered as highly complex mixtures, decrease the duration of TSW. As male salamanders can mate several times, reduced TSW time may increase the number of courtship encounters which result in successful sperm transfer. Behavioral studies indicated that the application of fewer isoforms of each pheromone can have different effects on female behavior [11, 19-21]. All three pheromone families have unique evolutionary origins and have been co-opted from different gene families: $\mathrm{PRF}$ is a $22 \mathrm{kDa}$ protein related to IL-6 cytokines, PMF is a $7 \mathrm{kDa}$ protein related to the highly diverse three-finger protein (TFP) superfamily, and SPF is a $20 \mathrm{kDa}$ protein related to $\gamma$-type phospholipase A2 inhibitors [11, 22, 23]. Although the three are considered discrete gene families, it has been hypothesized that the $\gamma$-type phospholipase A2 inhibitors may have arisen 
from the TFP superfamily [24]. Phylogenetic studies using RT-PCR in 28 plethodontid species revealed that PMF and SPF are relatively ancient pheromones (>100 million years old), while PRF is a more recent adaptation found only in the genus Plethodon (where some species employ olfactory delivery). Using these cDNA sequences, analysis of the $\mathrm{d}_{\mathrm{N}} / \mathrm{d}_{\mathrm{S}}$ ratios by PAML revealed all three families have undergone rapid evolution, likely due to sexual selection [23, 25, 26]. It is noteworthy that in newts (family Salamandridae), a homolog of SPF is cleaved to liberate a decapeptide (sodefrin) that is released by male aquatic newts to attract females [27], suggesting that the SPF family may have been co-opted multiple times within amphibians for pheromone activity.

Comparison of pheromone composition across different species and modes of delivery suggest that numerous pheromone gene co-option events have occurred across the plethodontid phylogeny. Recent proteomic analyses in the redback salamander (Plethodon cinereus) revealed that, despite using the transdermal mode of delivery, its pheromone composition was principally composed of PRF and PMF, similar to that of $P$. shermani (which uses slapping delivery) [28]. In a cDNA library screen comparing $P$. shermani with two distantly related scratching species (D. ocoee, and Eurycea guttolineata), SPF was suggested to be the major pheromone component. Additionally, three putative pheromones were identified with sequence similarity to peptide hormones (glucagon, natriuretic peptide, and relaxin). There were fewer PMF isoforms in these species and no expression of PRF. Therefore, although P. cinereus, D. ocoee, and E. guttolineata all use transdermal delivery, their pheromones may target unique receptors and produce genusspecific physiological effects [29]. To better understand changes in pheromone composition across plethodontid salamanders utilizing transdermal delivery, and gain insight into the forces that contribute to gene co-option, more comprehensive proteomic studies were required. 
Towards these goals, we characterized the composition of the $D$. ocoee mental gland extract using contemporary biochemical and mass spectral methods. Deeper cDNA sequencing and targeted PCR analyses permitted identification of previously uncharacterized putative pheromone genes and greater SPF isoform variation. Finally, pheromone composition was assessed between male salamanders and across different times throughout the courtship season to assess individual and temporal variation.

\section{Materials and Methods}

Animal collection, tissue removal, and pheromone extraction

Male D. ocoee salamanders were collected from Deep Gap in Clay County, North Carolina $\left(35^{\circ} 02^{\prime} 20^{\prime \prime} \mathrm{N} 083^{\circ} 33^{\prime} 08^{\prime \prime} \mathrm{W}\right)$ during the August breeding season. Animals were anesthetized in a mixture of $7 \%$ ether in water and mental glands surgically removed. Ten glands were immediately incubated in RNAlater (Ambion, Austin, TX) at $4^{\circ} \mathrm{C}$ overnight before long-term storage at $-20^{\circ} \mathrm{C}$. The remaining glands were incubated in $0.8 \mathrm{mM}$ acetylcholine chloride (in amphibian Ringer's solution; 20 glands per $1 \mathrm{~mL}$ ) for 1 hour to induce secretion of protein pheromones. The solution was centrifuged at 10,000 $x \mathrm{~g}$ for 10 minutes, the supernatant collected, and re-centrifuged prior to storage at $-80^{\circ} \mathrm{C}$. In order to examine pheromone expression across the complete courtship season, male D. ocoee were also collected from the same location at approximately 3 week intervals from late May until early October, and pheromone extracted from $\sim 20$ glands at each time point. Methods and animal care were approved by the University of Louisville's Institutional Animal Care and Use Committee (IACUC \#12041 to P.W. Feldhoff).

Preparation of a mental gland cDNA library 
RNA was extracted from two male mental glands using the RNeasy Mini Kit (Qiagen, Valencia, CA) according to the manufacturer's protocols. Double-stranded cDNA was synthesized using the Creator SMART cDNA Library Construction Kit (Clontech, Palo Alto, CA), cloned into pCR2.1 using the TOPO TA cloning kit (Invitrogen, Carlsbad, CA) and transformed into One Shot chemically competent E. coli cells (Invitrogen). Cells were plated on LB/agar plates with $50 \mu \mathrm{g} / \mathrm{mL}$ kanamycin to select for resistant clones. A total of 864 clones were isolated, inoculated into $150 \mu \mathrm{L}$ Circlegrow broth (MP Biomedical, Irvine, CA) and cultured overnight at $37^{\circ} \mathrm{C}$. From each culture, glycerol freezer stocks were prepared and $1 \mu \mathrm{L}$ aliquots used for colony PCR with M13 primers. PCR products were screened by gel electrophoresis, with those greater than 500 base pairs purified using the QIAquick PCR Purification kit (Qiagen), and supplied to the University of Louisville DNA Core Facility for automated Sanger-based DNA sequencing. To more thoroughly analyze SPF and additional pheromone diversity, gene specific primers were designed, targets amplified by PCR from five individual D. ocoee mental glands, and cloned and sequenced using the methods described above.

DNA sequencing, processing, and analysis

Nearly full-length cDNA sequences were processed using the DNASTAR package (Lasergene Version 7.1: DNASTAR, Madison, WI). Low quality sequences were filtered and contigs assembled using Seqman Pro. The open reading frame of each sequence was identified, translated using EditSeq, and full-length translations aligned with MegAlign using the ClustalW algorithm. All sequences were deposited into NCBI Genbank (Accession \# KP410906 KP410997). Unique sequences were compiled into a database for peptide mass fingerprinting analyses. The mean nucleotide and amino acid distances were calculated in MEGA 5 using a JTT 
matrix-based model, and analyses conducted using a maximum composite likelihood model with 500 bootstrap replicates.

Purification and mass spectral analysis of major pheromone components

Pheromone components were purified through a combination of strong anion-exchangeHPLC (Mono Q; Pharmacia, Piscataway, NJ), reverse phase-HPLC (RP-HPLC) (C-18; Grace Davison Discovery Sciences, Deerfield, IL), and size exclusion chromatography (G-75 Superfine; Pharmacia, Piscataway, NJ). All chromatographic separations were accomplished on a 2695 Alliance HPLC System equipped with a 2487 dual wavelength absorbance detector and Empower software (Waters Division, Milford, MA). The Mono Q column $(0.5$ x $5.5 \mathrm{~cm})$ was eluted at $1 \mathrm{ml} / \mathrm{min}$ with a $\mathrm{NaCl}$ gradient in $50 \mathrm{mM}$ Tris/ $\mathrm{HCl}$ buffer, $\mathrm{pH} 8.0$ (mixed gradient: 5 $\mathrm{mM} \mathrm{NaCl} / \mathrm{min}$ for $30 \mathrm{~min}, 10 \mathrm{mM} \mathrm{NaCl} / \mathrm{min}$ for $15 \mathrm{~min}, 20 \mathrm{mM} \mathrm{NaCl} / \mathrm{min}$ for $10 \mathrm{~min})$. The C18 column $(0.5 \times 15 \mathrm{~cm})$ was eluted with an acetonitrile $(\mathrm{ACN})$ gradient in $0.1 \%$ trifluoracetic acid. The G-75 column $(1.6 \times 15.5 \mathrm{~cm})$ was eluted at $\sim 10 \mathrm{~mL} / \mathrm{hr}$ with $0.5 \mathrm{X}$ phosphate-buffered saline, $\mathrm{pH} 7.4$ (PBS). D. ocoee pheromone extract was initially separated by size exclusion chromatography, pooled into three fractions which were then subjected to anion-exchange HPLC, with pooled anion-exchange fractions in turn analyzed by RP-HPLC and collected by hand for final purification (Figure S1). Individual proteins purified by RP-HPLC were analyzed by the University of Louisville Biomolecular Mass Spectrometry Core Facility, with intact protein mass determined by electrospray ionization mass spectrometry (ESI-MS) and protein identity ascertained from tryptic peptides analyzed by either matrix assisted laser desorption ionization-time of flight (MALDI-TOF) or Orbitrap liquid chromatography tandem mass spectrometry (LC/MS-MS). Protein reduction and alkylation with dithiothreitol (DTT) and iodoacetamide (IAA), respectively, were selectively used to identify cysteine residues. 
Experimental masses of the peptides were compared to a database of theoretical masses derived from $D$. ocoee cDNA sequences. To assess variation of pheromone types between individual male D. ocoee (and approximate levels of different SPF classes), pheromone was extracted from 6 individual $D$. ocoee mental glands, with $2 \mu \mathrm{g}$ aliquots subjected to overnight trypsin proteolysis, and analyzed by LC/MS-MS. Normalized spectral abundance factors (NSAF) for SPF classes were calculated using the Trans-Proteomic Pipeline [30].

Genomic analysis of SPF

Multiple genome walking techniques were employed to characterize the gene structure of SPF. Genomic DNA was purified from a single D. ocoee tail tip using overnight proteinase K digestion, phenol-chloroform-isoamyl alcohol extraction, and ethanol precipitation, and standardized to $200 \mathrm{ng} / \mu \mathrm{L}$. Based on the methods of Ochman et al. [31], gene specific primers were designed (see Table S1) for nested inverse PCR using the restriction enzymes Tsp509I, NlaIII, and HpyCH4IV in order to identify the terminal intron-exon boundary, since introns are generally not present in 3' untranslated regions (UTRs) [32]. PCR products were cloned, sequenced, and analyzed as described above. The terminal intron-exon boundary was determined by ascertaining the nucleotide position where inverse PCR sequenced failed to match the 3' end of SPF cDNA, and we observed the terminal 3' AG found in most nuclear introns. After the terminal SPF intron-exon boundary was determined by nested inverse PCR, subsequent boundaries were ascertained by degenerate PCR based on the methods of Guo and Xiong [33]. PCR products were analyzed by standard agarose gel electrophoresis, with well-defined bands selected for cloning, sequencing, and analysis as described above. Following determination of boundaries, primers were designed for known intron sequences and used to amplify across exons for verification that no additional introns existed in what were thought to be single exons. 


\section{Determination of SPF disulfide bonding pattern}

The disulfide bonding pattern of SPF was deduced using multiple proteolytic digests in the absence of reducing agent in order to maintain natural disulfides. Microgram quantities of the major SPF isoform were purified using a combination of anion-exchange and RP-HPLC as described above. Purified aliquots of SPF protein (3-5 $\mu \mathrm{g})$ were subjected to proteolysis by single or multiple endoproteinases (including trypsin, chymotrypsin, AspN, LysC, ArgC, GluC). For the in-solution digestion, lyophilized SPF protein was solubilized in $5 \mu \mathrm{L}$ of $4 \mathrm{M}$ Urea/ $/ 1 \mathrm{M}$ $\mathrm{NH}_{4} \mathrm{HCO}_{3}$, incubated for 30 minutes, diluted $50 \%$ with $0.1 \mathrm{M} \mathrm{NH}_{4} \mathrm{HCO}_{3}, 0.5 \mu \mathrm{g}$ of each protease added, and incubated overnight at $36^{\circ} \mathrm{C}$. Peptide fragments were purified by ZipTip (Millipore, Billerica, MA) according to the manufacturer's protocols and subjected to LC-MS/MS as described above. For in-gel digestion of SPF protein, aliquots were subjected to Tris-Tricine SDS-PAGE [34], stained with Coomassie Brilliant Blue R-250, and the appropriate gel band excised. The Coomassie stain was removed from the gel bands by repeated extraction in $50 \mathrm{mM}$ $\mathrm{NH}_{4} \mathrm{HCO}_{3}$ for 15 minutes followed by addition of an equal volume of $\mathrm{ACN}$, incubation for 15 minutes, and solvent removal. After complete Coomassie stain extraction, the remaining solvent was removed by centrifugal evaporation, $0.2 \mu \mathrm{g}$ of protease in $50 \mathrm{mM} \mathrm{NH}_{4} \mathrm{HCO}_{3}$ added to the sample, and incubated overnight at $36^{\circ} \mathrm{C}$. Liberated peptides were extracted from the gel by repeated rinses with $50 \mathrm{mM} \mathrm{NH}_{4} \mathrm{HCO}_{3}$ and $\mathrm{ACN}$, and analyzed by LC/MS-MS. Data were analyzed using the XMapper function in MassMatrix 2.4.2 [35].

\section{Results}

Analysis of the D. ocoee cDNA library 
A total of 235 high-quality sequences were collected from the D. ocoee cDNA library and assembled into contigs by Seqman Pro. The majority of contigs (82/107) were single sequence contigs, suggesting that a variety of transcripts are expressed at low basal rates. Sequences were grouped into four categories based on BLAST search results: pheromone/pheromone-like components, peptide hormone-like, housekeeping/cell maintenance genes, or unknown (Table 1). The majority of the single sequence contigs fell into the unknown category (i.e. no significant BLAST hit in Genbank to a protein with a known function). In order to focus on proteins that likely affect female behavior and physiology, a combination of molecular and proteomic approaches were used to characterize the pheromone-like and hormone-like components. Briefly, RT-PCR based sequencing was used to characterize the diversity of SPF in individual male salamanders. Coupled with proteomic analyses, one major SPF isoform was identified (SPF I-01), and became the target of gene structure and disulfide bond analyses. Cumulatively, these data support that SPF is homologous with the TFP superfamily (that also includes PMF), yet has a unique disulfide bonding pattern that likely results in a different tertiary structure. Analysis of the hormone-like components revealed several new families of putative pheromones that are derived from hormone-like peptides. Comparison with homologs from both $D$. ocoee and other vertebrates consistently revealed changes in motifs associated with prohormone processing and maturation that may alter both their activity and specificity relative to endocrine homologs.

\section{Examination of SPF cDNA sequences}

The most abundant pheromone-like component was SPF, comprising 2 contigs with a total of 19 sequences. To further characterize SPF isoform diversity and individual male variation, RT-PCR analysis was performed using RNA from mental glands of 5 individual male 
D. ocoee. Approximately 30 clones were sequenced from each male to yield a total of $150 \mathrm{SPF}$ sequences, resulting in 55 unique translations. Combining these results with those of a previous study [29], a total of 231 SPF sequences were analyzed. Upon translation and alignment, the majority (216/231) were classified into six separate classes based on sequence similarity and predicted biochemical properties such as charge and isoelectric point (pI) (Figure 1). Sequences within each class only varied by a few SNPs from the class consensus, and the number of amino acid substitutions per class was always $<1 \%$ (compared to $>20 \%$ variation between classes). Surprisingly, the remaining 15 sequences matched two or more different classes for different sections of the sequence and were termed hybrid sequences (Figure S2). Of the 231 sequences, 75 unique amino acid sequences were identified ranging from 192 to 200 amino acids, including a highly conserved 20 amino acid secretion signal peptide (Figure S3). Fifty three residues were completely conserved, including 9 in the signal peptide and 16 cysteine residues which form 8 disulfide bonds that likely stabilize the protein structure. While the most highly conserved segment was the signal peptide, an additional conserved region was located between amino acids 88 - 100 of the mature peptide which corresponds to a linker region between the two 8 cysteine halves of the protein. All SPF isoforms were predicted to be highly negatively charged at neutral $\mathrm{pH}(\bar{x} \pm \mathrm{SD}=-16.17 \pm 4.11)$.

For all 6 classes, the consensus sequence was always observed as a unique cDNA, and all other sequences in the alignment differed by only a few (1-5) SNPs. Individual translations that matched the class consensus sequence were identified multiple times (except Class V), but most other translations in a class were only identified once (Figure S3). The sequence that represented the consensus sequence for its class was given the number 01 to follow its class designation (e.g. SPF I-01 is the consensus sequence for class I). Only 17 of the 75 translations were identified 
multiple times, and SPF I-01 was identified 69 times ( 30\% of all sequences). Class I was the most highly represented with $46 \%$ of all sequences, followed by Class VI with $\sim 18 \%$ of sequences. Class VI was also the most divergent class by sequence similarity, and included five substitutions in the otherwise highly conserved signal peptide. Interestingly, class VI sequences contained a potential N-linked glycosylation site at residues 105-107 (-Asn-His-Thr-), with no putative N-linked glycosylation sites in the other SPF classes. Notably, Class V SPF was only identified in a single male and a single sequence was found for this class. Between classes, the average number of nucleotide substitutions per site was as high as 0.738 (Table S2) and the average amino acid similarity for all unique translations was $\sim 50 \%$.

In comparing the SPF cDNA sequences between the five individual males, the majority of sequences were unique to a particular male. Notably, males could express as many as 20 different SPF translations $(\bar{x} \pm \mathrm{SD}=13.8 \pm 5.1)$, suggesting that the total diversity of SPF is likely due to both allelic variation and gene duplication. Only the highly abundant SPF I-01 was identified in all males sampled, with seven more SPFs identified in multiple males: SPF I-16 (2 males), SPF I-19 (2 males), SPF II-01 (3 males), SPF III-01 (3 males), SPF IV-01 (3 males), SPF VI-01 (2 males), SPF VI-12 (2 males). Interestingly, these sequences tended to be the consensus sequences of their particular class. Comparison of class percentages within each male revealed highly variable transcript proportions, yet SPF I was consistently the most highly abundant class (Figure 2).

\section{SPF proteomic analysis}

In order to encompass the spring and fall mating seasons of D. ocoee, pheromone extract was collected from 20 males at approximate 3 week intervals from May through October. Reverse phase-HPLC analyses (RP-HPLC) of the pooled samples revealed similar pheromone 
profiles (Figure S4), with one major peak eluting at $\sim 36 \%$ ACN that comprised $\sim 30 \%$ of the pheromone extract (Figure 3). This protein was purified using a combination of chromatographic methods, including size-exclusion, anion-exchange, and RP-HPLC. Mass spectral analysis indicated a mass of 20,247 and a $90 \%$ peptide fingerprint match to SPF I-01. The 16 cysteine residues were confirmed to be disulfide bonded by reduction/alkylation experiments. Further analysis of pheromone fractions indicated the presence of another isoform of SPF (SPF IV-01; $80 \%$ sequence coverage), although at a much lower relative abundance.

Separation and purification of specific pheromone proteins from individual male $D$. ocoee is not feasible utilizing chromatographic methods because of the small gland size $(\sim 1 \mathrm{mg})$ and limited pheromone extract $(<30 \mu \mathrm{g}$ per gland). Therefore, to further investigate individual male variation of SPF at a proteomic level, a mass spectral proteomic analysis was conducted on whole extract from six individual animals. Pheromone was extracted from individual mental glands and $\sim 2 \mu \mathrm{g}$ aliquots were subjected to trypsin proteolysis prior to analysis by LC MS/MS. The resulting peptide matches were quantified as the normalized spectral abundance factor (NSAF). Peptides corresponding to all six SPF classes were observed in all males, with class I always the most highly expressed; however, in contrast to the cDNA analyses, protein levels for each class were similar between individual males ( $<5 \%$ variation; Figure $2 \mathrm{~B})$.

SPF genome walking and gene structure determination

SPF shares sequence similarity with the $\gamma$-type phospholipase A2 inhibitors (PLIs), which have been hypothesized to possess two 8 cysteine, TFP-like domains [24]. Upon alignment with other TFPs, SPF appeared to have these two TFP-like domains separated by a 15 amino acid linker. Each of these putative domains contained 6 cysteine residues that aligned with three of the four canonical TFP disulfide bonds (B1, B2 and B4; Figure 4), and an additional two cysteine 
residues that, in a smaller percentage of TFPs, form an additional disulfide bond within the first loop of the TFP structure. However, based on the cysteine spacing, SPF was missing the two cysteine residues that typically form the highly conserved B3 disulfide bond in other TFP members (Figure 4).

To further assess this tandem TFP domain hypothesis, the gene structure of SPF I-01 was investigated. TFPs generally have a gene structure of 3 exons- 2 introns, with the exons principally containing the signal peptide, the first 3 cysteines, and the last 5 cysteines, respectively [36]. Using multiple gene walking techniques, we identified four intron-exon boundaries, suggesting a gene structure with five exons and four very large introns (Figure 5). The first exon comprised the 5' UTR and the bulk of the signal peptide, with the first intron splitting amino acid 18 between the first and second nucleotides of the codon, similar to most TFPs. The second exon included the remainder of the signal peptide and the first 37 amino acids of the native protein, representing the first five cysteine residues (the first three TFP canonical Cys plus the additional bond in finger 1). The third exon of SPF contained the remainder of the first TFP-like domain and a portion of the linker between the two domains. The fourth exon corresponded to the remaining portion of the linker and the beginning of the second TFP-like domain, with the fifth exon containing the C-terminal coding region along with the full length 3' UTR ( 200 base pairs). Primers were designed between all consecutive introns to amplify the full length of each exon and ensure no additional splice boundaries. However, due to the large size of the $D$. ocoee genome ( $\sim \mathrm{X}$ larger than the human genome) and proportional increase in intron size [37], full intron sequences could not be readily amplified by PCR. However, the spacing of these exon-intron boundaries is consistent with that of two tandem TFP domains. SPF disulfide bonding pattern 
To further characterize the relation of SPF to the TFP superfamily, purified SPF I-01 was subjected to proteolysis with different enzyme combinations and analyzed by LC MS/MS. In total, 8 different protease digest reactions yielded 36 protein fragments that led to the complete deduction of the SPF disulfide bonding pattern (Table S3). Specifically, tryptic digests yielded a peptide that contained the first four cysteine residues, suggesting that these residues were bonded to one another. LC MS/MS fragmentation data from this peptide supported Cys1-Cys2 and Cys3Cys4 disulfide bonds. Two additional digests generated peptides containing the first two cysteine residues, further supporting Cys1-Cys2 and Cys3-Cys4 bonds. Proteolytic digestion with LysC generated a peptide corresponding to the first six cysteines in one disulfide bonded piece, implying a Cys5-Cys6 bond. Double cleavage reactions using both trypsin and chymotrypsin also generated this Cys5-Cys6 peptide in isolation. Bonds between Cys7 and Cys8 were supported by multiple proteolytic digests, suggesting sequential bonds (1-2, 3-4, 5-6, 7-8) for the first 8 cysteines. In the second domain, the Cys12-Cys16 bond was strongly supported by multiple digests and fragmentation data. Additional peptide fragments were found to support the disulfides Cys9-Cys13 and Cys10-Cys11. By deduction, Cys14-Cys15 must be paired. Overall, this leads to a complete disulfide bonding pattern of 1-2, 3-4, 5-6, 7-8, 9-13, 10-11, 12-16, 14-15 which is distinct from the canonical TFP pattern (Figure 4).

\section{Characterization of D. ocoee PMF}

It was of interest to further characterize PMF expression in D. ocoee because of its prevalence in both $P$. shermani and $P$. cinereus pheromone extracts. Four sequences in the $D$. ocoee cDNA library were identified as PMF and translated to the same polypeptide sequence, with 85 amino acids including a 19 amino acid secretion signal peptide. PCR amplification using primers designed to anneal to conserved portions of D. ocoee PMF 5' and 3' UTRs failed to 
identify any additional isoforms. Mass spectral analysis identified the PMF protein as a peak eluting at $\sim 24 \%$ ACN by RP-HPLC, which is more hydrophilic than both $P$. shermani and $P$. cinereus PMFs ( $\sim 30-35 \%$ ACN elution). Unlike the highly negatively charged PMF isoforms identified in $P$. shermani, the D. ocoee PMF was predicted to have a +1 charge at $\mathrm{pH}$ 7.4. Unsurprisingly, the protein eluted near the beginning of the salt gradient by anion exchange HPLC $(<20 \mathrm{mM} \mathrm{NaCl})$. The PMF protein peak represented $<1 \%$ of the total pheromone mixture and is a relatively minor component compared to SPF, but its biological activity and function are unknown.

\section{Characterization of hormone-like peptides}

A surprisingly large number of sequences in the shotgun cDNA sequences had BLAST results with similarity to hormone-like peptides (76 sequences; Table 1). Specific sequences were identified that showed similarity to glucagon (26 sequences), vasoactive intestinal peptide (VIP; 34 sequences), relaxin (6 sequences), insulin (3 sequences) leptin (2 sequences), and five additional single sequence contigs. To further investigate these hormone-like peptides and uncover any additional variability, primers were designed to anneal to conserved regions of the 5' UTRs and amplified by RT-PCR. Only isoforms sequenced more than once were given specific names/numbers, with additional variation appropriately noted.

Glucagon and VIP are both members of the glucagon/secretin family that also includes glucagon-like peptide 1 (GLP1), glucagon-like peptide 2 (GLP2), secretin, gastric inhibitory peptide and pituitary adenylate cyclase-activating peptide. This diverse set of hormones range in size from 27 to 42 amino acids in length and are cleaved from larger precursor proteins [38]. The glucagon-like and VIP-like proteins from the D. ocoee mental gland (termed mental gland Glucagon-like Peptide, mgGLP, and VIP-Like Peptide, VLP, respectively) each contained a 
secretion signal and dibasic sites for cleavage of the native peptides which would generate lengths of 32 and 43 amino acids, respectively. Three isoforms of mgGLP (mgGLP1-3) comprised $79 \%$ of the sequence variation beyond 1-2 SNPs (possibly representing Taq errors) (Figure 6A). mgGLP2 matches a sequence that had been previously identified in a $D$. ocoee EST library [29], and mgGLP1 only varies from mgGLP2 by a single, likely neutral, amino acid change (T73S). In contrast, the processed mgGLP3 only shares $45 \%$ amino acid identity with mgGLP1/mgGLP2. The VIP-like proteins (VLPs) had six translations (Figure 6A) representing $76 \%$ of sequences, with the remaining $24 \%$ varying by no more than 3 SNPs. Of the six translations, there were three major types each having two putative alleles: VLP1/2, VLP3/4 and VLP 5/6. Because of similarity in the glucagon/secretin superfamily, a gene tree was prepared comparing the D. ocoee processed peptides to the native glucagon, GLP1, GLP2 and VIP peptides from other species (Figure S5), including those from D. ocoee based on draft liver and pancreas transcriptomes (Wilburn and Feldhoff, unpublished data). This gene tree confirmed the relationship between the VLPs and VIP. However, while mgGLP1 and mgGLP2 were most similar to glucagon, mgGLP3 was most similar to GLP1. Compared to their respective counterparts from other species, mgGLPs and VLPs tended to be longer and contain many residues implicated in receptor binding and/or activation of biological activity (Figure 6B).

Relaxin and insulin are both members of the insulin superfamily [39]. Proteins in this family are composed of a B chain and an A chain that contain six cysteine residues which form one intrachain and two interchain disulfide bonds. The native peptide is cleaved from a precursor arranged with a signal peptide, the $\mathrm{B}$ chain, the removed $\mathrm{C}$ peptide, and the A chain [40]. In the D. ocoee, mental gland, three major translations of insulin-like proteins (ILP) were identified (Figure 7). Two of these translations, ILP1 and ILP2, differed by a single amino acid 
substitution and may represent allelic variants. The third translation, ILP3 differed from ILP1/2 by 18 amino acids. The mental gland ILP sequences were distinct from the pancreatic insulin sequence. However, the ILPs lacked the second dibasic cleavage site to remove the C-peptide from the A chain, which is conserved in all other members of the insulin superfamily. Thus, the ILPs may consist of a B chain disulfide bonded to a large C+A peptide. Of the hormone-like sequences from the mental gland, the relaxin-like proteins (RLPs) had the most variability, with 22 different translations from 44 cDNA sequences. These predicted proteins were grouped into four different classes based on sequence similarity with class members differing by $<5$ SNPs. The RLPs were less conserved compared to relaxins of other species; however, many residues involved in receptor binding as well as the conserved cysteine residues are maintained (Figure 8) $[41,42]$.

The final category of hormone-like sequence was a Leptin-Like Protein (LLP). Leptin is a $16 \mathrm{kDa}$ protein hormone that regulates food intake and metabolism [43]. The predicted mental gland LLP was 168 amino acids in length, including a 21 amino acid secretion signal. This sequence shared $60 \%$ and $44 \%$ amino acid identity to leptin in tiger salamanders (Ambystoma tigrinum) and Xenopus tropicalis, respectively.

Additional purification of D. ocoee proteins and mass spectral analysis matched three purified protein peaks to RLP sequences. Because hormones are effective in small amounts and are generally of low molecular weight, the mental gland products may not be detectable by liquid chromatography. However, these proteins were visible in the tryptic MS data sets acquired for whole pheromone of six individual male $D$. ocoee (used to characterize proteomic variation in SPF classes above). All six males expressed each type of hormone-like peptides, but with variation of the isoform classes. Specifically, LLP was detected in all six males; all four classes 
of RLP were detected in four males, while the other two males were missing either RLP3 or RLP4. Similarly, mgGLP1 and mgGLP3 were detected in four males, while two males were each missing mgGLP1 or mgGLP3. mgGLP2 was not identified in any of the males. Five of the six males had all three major types of VLP sequences with one male missing a VLP 3/4. All six males had either ILP1 or ILP2 with three also having ILP3.

\section{Discussion}

\section{Recruitment of novel pheromone families by gene co-option}

For more than 100 million years, plethodontid salamanders have utilized a unique system of courtship pheromones to regulate female mating behavior and physiology. In all molecular and proteomic studies to date, we have demonstrated recruitment and co-option of multiple gene families followed by rapid evolution [23, 25, 26, 28, 44]. Specifically, our proteomic studies demonstrate large changes in pheromone composition between genera, even for those using the same delivery mode $[28,45]$. A key question remains is what factors allow a gene to be coopted. Because the mental gland develops in response to elevated plasma androgens [46, 47], it is likely that plethodontid pheromone genes are directly or indirectly stimulated by the androgen receptor. In support of this, there are predicted androgen receptor response elements in the promoters of at least some P. shermani PMFs (Wilburn and Feldhoff, unpublished data). In addition to changes in regulatory regions to promote expression in the mental gland, co-opted genes must acquire new functions (neofunctionalization) through mutation that provide a selective advantage to the males possessing these novel traits.

As signaling proteins that travel in the blood and modulate physiology, peptide hormones already possess functions that may be rapidly co-opted. Like other plethodontid pheromones, 
our data support that the hormone-like peptides in the mental gland of D. ocoee are products of gene duplication. One important difference that many of the mental gland hormone-like peptides share, compared to their progenitors, is the loss of key residues important for cleavage of the native peptides. For example, glucagon and VIP in other species have a consistent length of 29 and 28 amino acids, respectively $[48,49]$, whereas the mgGLP and VLP lack the canonical dibasic cleavage site that typically follows those positions and instead possess downstream dibasic sites that extend their C-termini. Additionally, all three predicted D. ocoee ILPs lack a dibasic site on the $\mathrm{C}$-terminal end of the $\mathrm{C}$-peptide, which would normally cleave it from the Achain [50]. One hypothesis is that these changes in processing sites have altered the mental gland peptides so that they no longer activate the receptors of the hormones from which they were derived. However, the mental gland hormone-like proteins do show conservation in many residues that are implicated in receptor binding. For example, mgGLP1/2 has eight of the key residues implicated in receptor binding and/or activation [51]; similarly, the VLPs contained 10 of the 14 residues necessary for VIP receptor binding and biological activity [52]. The D. ocoee ILPs have many residues important for insulin receptor binding/or activity, including L6, V12, F25, and Y26 in the B chain and G1, I2, and V3 in the A chain [53]. Because of this conservation, the hormone-like peptides may be recognized by receptors on a number of target organs, although it is unclear if they would function as agonists or antagonists, and at what affinity. However, small amounts of these proteins may have significant effects on female physiology by directly targeting key organs and cells.

The hormones from which the D. ocoee mental gland proteins are derived have many diverse functions including vasodilation [54], gut secretion of sodium and chloride ions [55], immune system modulation [56], exocrine gland secretion [57] and smooth muscle relaxation 
[58]. However, particularly noting glucagon, insulin, and leptin, one common function may be metabolic regulation [43, 59]. It is well established that energy balance has a direct and prominent effect on reproductive success [60]. Since metabolic hormones regulate energy balance, they also serve as signals of energy state and are used to prioritize behaviors depending on energy condition [61]. It is possible that the hormone-like peptides are directly influencing metabolism in $D$. ocoee females in order to emulate a state more favorable towards mating and reproduction. In $P$. shermani, pheromones delivered by olfaction decrease female feeding behavior, apparently by enhancing a preference for male scent over food scent $[62,63]$. In species using transdermal delivery, it may be possible to directly induce these same effects by binding to tissue-specific receptors and not relying on neurological circuits in the olfactory system.

The origin and evolution of SPF diversity

While peptide hormones have pre-existing functions that might make them predisposed to pheromone co-option, the origin of SPF - the major D. ocoee pheromone - was more difficult to immediately infer. Using alignment of cDNA sequences and by defining the intron-exon splice sites, we provide direct evidence that SPF shares a common gene ancestry with the TFP superfamily. Recent investigations of SPF sequences in multiple genera of newts (family Salamandridae) provide additional support for SPF being a "double TFP" [64]. PMF is also a member of the TFP superfamily, suggesting common recruitment from the same protein family [65]. While TFPs perform a plethora of biological functions in vertebrates (including regulation of the complement system [66], amphibian limb regeneration [67], and tissue reorganization [68]), they are generally most well-known as components of snake venoms [69]. Comparison of venomous vs. non-venomous snake genomes supports extensive gene duplication and co-option 
to expand the breadth of prey and tissue types that may be targeted using a common venom cocktail [70]. The success of TFPs in functional co-option has been attributed to their small size ( 60-100 residues), lack of antigenicity, and extreme tolerance to temperature, various solvents, and most proteases [71]. These properties result from the highly disulfide-bonded, $\beta$-sheet scaffold that provides the namesake "three-finger" fold [72]. However, we report that numerous mutations have significantly altered the SPF disulfide bonding pattern and likely the protein topology. While SPF has cysteine residues that align to those that form highly conserved TFP bonds B1, B2, B4, and B1A, the same disulfide connectivities are not shared. SPF is also missing the cysteine residues that typically result in the highly conserved TFP bond B3 (Figure 4); however, this bond is also missing in the first TFP domain of uPAR [73], and also does not participate in a highly organized van der Waals network between B1, B2, and B4 in all other TFPs [72]. Interestingly, the sodefrin precursor in newts (for which SPF was originally named) does not have cysteine spacing consistent with a tandem TFP; instead, there is a single TFP-like domain with B1, B2, B3, B4 and B1A, and an extended C-terminal domain with additional cysteine residues. Non-canonical disulfides in the TFP superfamily have only been reported for the first uPAR domain and in a $P$. shermani PMF $[74,75]$. In the latter case, NMR studies revealed that these altered disulfides permitted greater backbone flexibility in the most rapidly evolving segments of the protein, which correspond to the putative receptor binding region [75]. Consequently, SPF represents another instance of TFP co-option and structural modification within plethodontid salamanders for pheromone activity.

A common theme among plethodontid salamander pheromones is extensive isoform diversity and signatures of positive selection $[26,44,76]$. In this report, we more thoroughly investigated the molecular and proteomic diversity of SPF in D. ocoee. Similar to PMF evolution 
in species with olfactory delivery [44], the SPF sequence diversity in D. ocoee was most accurately described as multiple highly divergent gene classes with very low levels of withinclass variation. This pattern likely emerged through an ancestral burst of gene duplications followed by positive selection to generate the six classes, with the additional minor variants that we observe today likely maintained by purifying selection and/or representing recent gene duplications that have had little time to drift. This mode of evolution would be similar to that for snake venom TFPs. Maintenance of the multiple SPF isoforms may extend from relaxed purifying selection as a secreted protein that has few interactions with mental gland cytosolic proteins (for thorough review of how gene duplication and sexual selection may affect reproductive protein evolution, see [45]). Interestingly, nearly all of the sequence diversity seems to be due to gene duplication, with an individual $D$. ocoee mental gland having at least 20 different variants. The observation of "hybrid" SPFs with segments of more than one gene class was suggestive of possible exon swapping; however, the "switching points" for these hybrid sequences were highly variable and did not align with the identified intron-exon splice sites. Unfortunately, the number of SPF genes (and complete gene sequences) remain difficult to determine. This is in part due to the length of salamander introns (10-20X the size of vertebrate orthologs) [77] and the exceptional size of plethodontid salamander genomes (5-10X larger than the human genome). The one commonality between switching points was that they tended to be in more conserved regions between the two classes, making gene conversion and/or crossing over a more likely explanation [78]. A similar phenomenon was observed in viperid snake venom TFP genes, where short segments of exons are exchanged to permit rapid remodeling of the protein surface for functional modulation (termed Accelerated Segment Switch in Exons to 
alter Targeting, ASSET). However, the molecular mechanisms that drive ASSET are not understood [79].

Variation in SPF class expression between individual males was jointly assessed at both mRNA (using RT-PCR and clone counts) and protein levels (using LC/MS-MS). Despite variable clone frequencies between individuals (Figure 3), mass spectral count estimates of protein abundance were highly consistent. Part of this discrepancy may be explained from sampling bias in both assays, particularly the cDNA clone counts which are low resolution data (6 SPF classes measured by $\sim 30$ clones per male). However, RNA-protein levels do not often correlate well for biological reasons. For example, in a global screen comparing levels in Saccharomyces cerevisiae, the correlation coefficient was only $\sim 0.6$ [80]. Additionally, protein levels are more conserved than mRNA abundance across different taxa [81]. Consequently, posttranscriptional gene regulation cannot be ruled out and SPF mRNAs may be subject to differential rates of translation. Preliminary results from $P$. shermani suggest that RNA binding proteins play a key role in controlling pheromone synthesis (Wilburn and Feldhoff, unpublished data), and similar regulatory mechanisms might occur in $D$. ocoee. Relatively uniform expression of SPF proteins may indicate that individual female salamanders express the same SPF receptors and male expression patterns have converged to yield a single pheromone profile that maximizes female receptivity within the population. However, measuring rates of translation is difficult and susceptible to many methodology biases $[82,83]$ such that differential translation is just one possible explanation for these data. Future studies will further explore this hypothesis using higher resolution experiments such as RNA-Seq [84], ribosome profiling [85], and selective reaction monitoring mass spectrometry [86]. 
Generally, gene duplications are thought to be lost quickly within a population and are more likely to become fixed if the duplication itself is selectively advantageous due to increased expression [87]. Therefore, the rapid evolution of SPF from related molecules (PLI, sodefrin, and an original progenitor TFP) may be accounted for by a model of adaptive radiation [88]. Within this model, both gene duplication and mutation would be influenced by positive selection leading to increased fixation rates of gene duplications [87] and enhanced diversity. For SPF, such a model would suggest that a single ancestral SPF isoform had the ability to strongly stimulate a particular type of female receptor, but had lower affinity for mutated female receptors. Males with greater SPF expression from higher gene copy number may increase stimulation of mutated female receptors by dosage compensation, and therefore have greater reproductive success. Positive selection would then lead to increased fixation of gene duplications and simultaneously provide more copies for mutation and refinement of alternative isoforms. Because the mental gland is a specialized tissue solely dedicated to the synthesis and secretion of proteinaceous courtship pheromones that are delivered externally, it is unlikely to suffer the metabolic problems generally associated with increased gene dosage. A similar model of adaptive radiation has been evaluated in $E$. coli where leaky lac $Z$ mutant genes were duplicated to increase growth under selection on lactose and had the secondary effect of providing additional material for mutation leading to an increased $l a c Z^{+}$reversion rate [89]. In the case of SPF, the continuous selection would be the pressure to stimulate rapidly evolving female receptors. Such patterns of diversification through rapid gene duplication and positive selection are those under similar constant selective pressure through predator-prey relationships [90], reproduction [91], chemosensory reception [92] , or host defense and immunity [93]. 


\section{Conclusions}

For the first time, we have defined the vast majority of the proteomic and molecular diversity of pheromones in the D. ocoee mental gland, where several gene families have been coopted for likely pheromone activity. Multiple hormone-like peptides were identified at both the cDNA and protein levels, and may function to affect female physiology to enhance mating success. We report that SPF, and likely the entire phospholipase A2 inhibitor family, share a common ancestry with the TFP superfamily. More recently, SPF has acquired mutations that have resulted in a novel disulfide bonding pattern that presumably enhances its pheromone activity. The diversity in SPF can be represented by six classes that are expressed in the pheromone mixture at a stable level between individual males. Compared to other plethodontid salamanders, our data cumulatively support that novel co-option events have occurred in a lineage-dependent manner as part of a continued cycle of gene recruitment, duplication, and rapid evolution in order to maximize male reproductive success. Taken together, these studies suggest that the "pheromone" mixtures of male plethodontid salamanders may be extraordinarily complex. Future studies will seek to investigate the diversity of pheromones in additional scratching species, and uncover the molecular mechanisms by which these unique protein pheromones, including hormone-like peptides, affect female reproductive physiology.

\section{Acknowledgements}

We thank Lynne D. Houck (LDH), Stevan Arnold, Sarah Eddy, Adam Chouinard, Gwen Bury, Karen Kiemnec-Tyburczy, and Sean Darrow for assistance in the field, the University of Louisville Biomolecular Mass Spectrometry Core Laboratory (William Pierce, Jian Cai, Ned Smith) for their continued support, and the Highlands Biological Station (HBS) for continued 
support of our field research efforts. We also thank the three anonymous reviewers for their insightful comments on the manuscript. Funding was provided in part by National Science Foundation (Collaborative) grants IOS-1146899 (RCF) and IOS-1147271 (LDH), a HBS Grantin-Aid to KAD, and the University of Louisville EVPRI program.

\section{References}

[1] Gould SJ. The panda's thumb : more reflections in natural history. New York: Norton; 1980. [2] Bridgham JT, Carroll SM, Thornton JW. Evolution of hormone-receptor complexity by molecular exploitation. Science. 2006;312:97-101.

[3] Hughes AL. The evolution of functionally novel proteins after gene duplication. Proceedings of the Royal Society of London Series B: Biological Sciences. 1994;256:119-24.

[4] Li W-H. Rate of gene silencing at duplicate loci: a theoretical study and interpretation of data from tetraploid fishes. Genetics. 1980;95:237-58.

[5] Ingolia TD, Craig EA. Four small Drosophila heat shock proteins are related to each other and to mammalian alpha-crystallin. Proceedings of the National Academy of Sciences. 1982;79:2360-4.

[6] Parsell D, Lindquist S. The function of heat-shock proteins in stress tolerance: degradation and reactivation of damaged proteins. Annual Review of Genetics. 1993;27:437-96.

[7] Moczek AP, Rose DJ. Differential recruitment of limb patterning genes during development and diversification of beetle horns. Proceedings of the National Academy of Sciences. 2009;106:8992-7.

[8] Knox K, Baker JC. Genomic evolution of the placenta using co-option and duplication and divergence. Genome Res. 2008;18:695-705.

[9] Cross J, Baczyk D, Dobric N, Hemberger M, Hughes M, Simmons D, et al. Genes, development and evolution of the placenta. Placenta. 2003;24:123-30.

[10] Keys DN, Lewis DL, Selegue JE, Pearson BJ, Goodrich LV, Johnson RL, et al. Recruitment of a hedgehog regulatory circuit in butterfly eyespot evolution. Science. 1999;283:532-4. [11] Rollmann SM, Houck LD, Feldhoff RC. Proteinaceous Pheromone Affecting Female Receptivity in a Terrestrial Salamander. Science. 1999;285:1907-9.

[12] Houck LD, Reagan NL. Male courtship pheromones increase female receptivity in a plethodontid salamander. Animal Behavior. 1990;39:729-34.

[13] Wirsig-Wiechmann CR, Houck LD, Feldhoff PW, Feldhoff RC. Pheromonal activation of vomeronasal neurons in plethodontid salamanders. Brain Res. 2002;952:335-44.

[14] Laberge F, Feldhoff RC, Feldhoff PW, Houck LD. Courtship pheromone-induced c-Foslike immunolabeling in the female salamander brain. Neuroscience. 2008;151:329-39.

[15] Wyatt T. Pheromones and signature mixtures: defining species-wide signals and variable cues for identity in both invertebrates and vertebrates. Journal of Comparative Physiology A: Neuroethology, Sensory, Neural, and Behavioral Physiology. 2010;196:685-700. 
[16] Houck LD, Arnold SJ. Courtship and mating behavior. In: Sever DM, editor. Phylogeny and reproductive biology of Urodela (Amphibia). Enfield, New Hampshire: Science Publishers; 2003. p. 383-424.

[17] Arnold SJ. The evolution of courtship behaviors in salamanders. [Dissertation]: University of Michigan; 1972.

[18] Kiemnec-Tyburczy KM, Woodley SK, Feldhoff PW, Feldhoff RC, Houck LD. Dermal application of courtship pheromones does not influence receptivity in female red-legged salamanders (Plethodon shermani). Journal of Herpetology. 2011;45:169-73.

[19] Houck LD, Palmer C, Watts R, Arnold S, Feldhoff P, Feldhoff R. A new vertebrate courtship pheromone, PMF, affects female receptivity in a terrestrial salamander. Animal Behaviour. 2007;73:315-20.

[20] Houck LD, Watts RA, Mead LS, Palmer CA, Arnold SJ, Feldhoff PW, et al. A new candidate pheromone, SPF, increases female receptivity in a salamander. In: Hurst J, Beynon R, editors. Chemical Signals in Vertebrates. New York: Springer; 2007. p. 213-30.

[21] Wilburn DB, Eddy SL, Chouinard AJ, Arnold SJ, Feldhoff RC, Houck LD. Pheromone isoform composition differentially affects female behaviour in the red-legged salamander, Plethodon shermani. Animal Behaviour. 2015;100:1-7.

[22] Palmer CA, Hollis DM, Watts RA, Houck LD, McCall MA, Gregg RG, et al. Plethodontid modulating factor, a hypervariable salamander courtship pheromone in the three-finger protein superfamily. Febs J. 2007;274:2300-10.

[23] Palmer CA, Watts RA, Houck LD, Picard AL, Arnold SJ. Evolutionary replacement of components in a salamander pheromone signaling complex: more evidence for phenotypicmolecular decoupling. Evolution. 2007;61:202-15.

[24] So S, Chijiwa T, Ikeda N, Nobuhisa I, Oda-Ueda N, Hattori S, et al. Identification of the B subtype of gamma-phospholipase A2 inhibitor from Protobothrops flavoviridis serum and molecular evolution of snake serum phospholipase A2 inhibitors. J Mol Evol. 2008;66:298-307. [25] Palmer CA. Lineage-Specific Differences in Evolutionary Mode in a Salamander Courtship Pheromone. Molecular Biology and Evolution. 2005;22:2243-56.

[26] Palmer CA, Watts RA, Hastings AP, Houck LD, Arnold SJ. Rapid evolution of plethodontid modulating factor, a hypervariable salamander courtship pheromone, is driven by positive selection. J Mol Evol. 2010;70:427-40.

[27] Kikuyama S, Toyoda F, Ohmiya Y, Matsuda K, Tanaka S, Hayashi H. Sodefrin: a femaleattracting peptide pheromone in newt cloacal glands. Science. 1995;267:1643-5.

[28] Wilburn DB, Bowen KE, Feldhoff PW, Feldhoff RC. Proteomic analyses of courtship pheromones in the redback salamander, Plethodon cinereus. Journal of Chemical Ecology. 2014;40:928-39.

[29] Kiemnec-Tyburczy KM, Watts RA, Gregg RG, von Borstel D, Arnold SJ. Evolutionary shifts in courtship pheromone composition revealed by EST analysis of plethodontid salamander mental glands. Gene. 2009;432:75-81.

[30] Pedrioli P. Trans-Proteomic Pipeline: a pipeline for proteomic analysis. In: Hubbard S, Jones A, editors. Proteome Bioinformatics: Humana Press; 2010. p. 213-38.

[31] Ochman H, Gerber AS, Hartl DL. Genetic applications of an inverse polymerase chain reaction. Genetics. 1988;120:621-3.

[32] Deutsch M, Long M. Intron-exon structures of eukaryotic model organisms. Nucleic Acids Research. 1999;27:3219.

[33] Guo H, Xiong J. A specific and versatile genome walking technique. Gene. 2006;381:18-23. 
[34] Schägger H, von Jagow G. Tricine-sodium dodecyl sulfate-polyacrylamide gel electrophoresis for the separation of proteins in the range from 1 to $100 \mathrm{kDa}$. Analytical Biochemistry. 1987;166:368-79.

[35] Xu H, Freitas MA. MassMatrix: a database search program for rapid characterization of proteins and peptides from tandem mass spectrometry data. Proteomics. 2009;9:1548-55.

[36] Georgaka E, Nastopoulos V, Eleftheriou S, Zarkadis IK. A toxin-like gene in rainbow trout: cloning, expression, and gene organization. Toxicon. 2007;49:1002-9.

[37] Smith JJ, Putta S, Zhu W, Pao GM, Verma IM, Hunter T, et al. Genic regions of a large salamander genome contains long introns and novel genes. BMC Genomics. 2009;10.

[38] Rodbell M, Birnbaumer L, Pohl SL, Sundby F. The reaction of glucagon with its receptor: evidence for discrete regions of activity and binding in the glucagon molecule. Proceedings of the National Academy of Science USA. 1971;68:909.

[39] Shabanpoor F, Separovic F, Wade JD. The human insulin superfamily of polypeptide hormones. Vitamins \& Hormones. 2009;80:1-31.

[40] James R, Niall H, KWOK S, BRYANT-GREENWOOD G. Primary structure of porcine relaxin: homology with insulin and related growth factors. 1977.

[41] Bathgate RAD, Samuel CS, Burazin TCD, Gundlach AL, Tregear GW. Relaxin: new peptides, receptors and novel actions. Trends in Endocrinology \&amp; Metabolism.

2003;14:207-13.

[42] Evans BA, John M, Fowler KJ, Summers RJ, Cronk M, Shine J, et al. The mouse relaxin gene: nucleotide sequence and expression. Journal of Molecular Endocrinology. 1993;10:15-23. [43] Halaas JL, Gajiwala KS, Maffei M, Cohen SL, Chait BT, Rabinowitz D, et al. Weightreducing effects of the plasma protein encoded by the obese gene. Science. 1995;269:543-6. [44] Wilburn DB, Bowen KE, Gregg RG, Cai J, Feldhoff PW, Houck LD, et al. Proteomic and UTR analyses of a rapidly evolving hypervaraible family of vertebrate pheromones. Evolution. 2012;66:2227-39.

[45] Wilburn DB, Swanson WJ. From molecules to mating: Rapid evolution and biochemical studies of reproductive proteins. Journal of Proteomics. 2015;in press.

[46] Sever DM. Induction of secondary sexual characters in Eurycea quadridigitata. Copeia. 1976:830-3.

[47] Woodley SK. Plasma androgen levels, spermatogenesis, and secondary sexual characteristics in two species of Plethodontid salamanders with dissociated reproductive patterns. General and Comparative Endocrinology. 1994;96:206-14.

[48] Bromer WW, Boucher ME, Patterson JM, Pekar AH, Frank BH. Glucagon Structure and Function I. PURIFICATION AND PROPERTIES OF BOVINE GLUCAGON AND MONODESAMIDOGLUCAGON. Journal of Biological Chemistry. 1972;247:2581-5. [49] Mutt V, Said SI. Structure of the porcine vasoactive intestinal octacosapeptide. European Journal of Biochemistry. 1974;42:581-9.

[50] Chance RE, Ellis RM. Proinsulin: Single-chain precursor of insulin. Archives of Internal Medicine. 1969;123:229.

[51] Unson CG, Merrifield RB. Identification of an essential serine residue in glucagon: implication for an active site triad. Proceedings of the National Academy of Sciences. 1994;91:454-8.

[52] Nicole P, Lins L, Rouyer-Fessard C, Drouot C, Fulcrand P, Thomas A, et al. Identification of Key Residues for Interaction of Vasoactive Intestinal Peptide with Human VPAC1 and 
VPAC2Receptors and Development of a Highly Selective VPAC1Receptor Agonist. Journal of Biological Chemistry. 2000;275:24003-12.

[53] Nakagawa SH, Tager HS, Steiner DF. Mutational Analysis of Invariant Valine B12 in Insulin: Implications for Receptor Binding $\dagger$. Biochemistry. 2000;39:15826-35.

[54] Greenberg B, Rhoden K, Barnes PJ. Relaxant Effects of Vasoactive Intestinal Peptide and Peptide Histidine Isoleucine in Human and Bovine Pulmonary Arteries. Blood Vessels. 1987;24:45-50.

[55] Schwartz CJ, Kimberg DV, Sheerin HE, Field M, Said SI. Vasoactive intestinal peptide stimulation of adenylate cyclase and active electrolyte secretion in intestinal mucosa. Journal of Clinical Investigation. 1974;54:536.

[56] Delgado M, Pozo D, Ganea D. The significance of vasoactive intestinal peptide in immunomodulation. Pharmacological Reviews. 2004;56:249-90.

[57] Lundberg JM, Änggärd A, Fahrenkrug J, Hökfelt T, Mutt V. Vasoactive intestinal polypeptide in cholinergic neurons of exocrine glands: functional significance of coexisting transmitters for vasodilation and secretion. Proceedings of the National Academy of Sciences. 1980;77:1651-5.

[58] Szlachter N, O'Byrne E, Goldsmith L, Steinetz B, Weiss G. Myometrial inhibiting activity of relaxin-containing extracts of human corpora lutea of pregnancy. American journal of obstetrics and gynecology. 1980;136:584.

[59] Kamohara S, Burcelin R, Halaas JL, Friedman JM, Charron MJ. Acute stimulation of glucose metabolism in mice by leptin treatment. Nature. 1997;389:374-7.

[60] Bronson FH. Mammalian reproductive biology: University of Chicago Press; 1989.

[61] Schneider JE. Energy balance and reproduction. Physiol Behav. 2004;81:289-317.

[62] Vaccaro EA, Feldhoff PW, Feldhoff RC, Houck LD. Male courtship pheromones suppress female tendency to feed but not to flee in a plethodontid salamander. Animal Behaviour. 2009;78:1421-5.

[63] Baggett CL, Wilburn DB, Feldhoff RC, Houck LD. Female scent preference is jointly modulated by mating receptivity and male courtship pheromones in the red-legged salamander. Animal Behaviour. 2015; submitted.

[64] Janssenswillen S, Vandebergh W, Treer D, Willaert B, Maex M, Van Bocxlaer I, et al. Origin and Diversification of a Salamander Sex Pheromone System. Molecular Biology \& Evolution. 2014; in press.

[65] Palmer CA, Hollis DM, Watts RA, Houck LD, McCall MA, Gregg RG, et al. Plethodontid modulating factor, a hypervariable salamander courtship pheromone in the three-finger protein superfamily. FEBS Journal. 2007;274:2300-10.

[66] Davies A, Simmons DL, Hale G, Harrison RA, Tighe H, Lachmann PJ, et al. CD59, an LY6-like protein expressed in human lymphoid cells, regulates the action of the complement membrane attack complex on homologous cells. The Journal of Experimental Medicine. 1989;170:637-54.

[67] Garza-Garcia A, Harris R, Esposito D, Gates PB, Driscoll PC. Solution structure and phylogenetics of Prod1, a member of the three-finger protein superfamily implicated in salamander limb regeneration. PLoS ONE. 2009;4:e 7123.

[68] Blasi F, Carmeliet P. uPAR: a versatile signalling orchestrator. Nat Rev Mol Cell Biol. 2002;3:932-43. 
[69] Fry BG. From genome to "venome": molecular origin and evolution of the snake venom proteome inferred from phylogenetic analysis of toxin sequences and related body proteins. Genome Research. 2005;15:403-20.

[70] Vonk FJ, Casewell NR, Henkel CV, Heimberg AM, Jansen HJ, McCleary RJR, et al. The king cobra genome reveals dynamic gene evolution and adaptation in the snake venom system. Proceedings of the National Academy of Sciences. 2013.

[71] Naimuddin M, Kobayashi S, Tsutsui C, Machida M, Nemoto N, Sakai T, et al. Directed evolution of a three-finger neurotoxin by using cDNA display yields antagonists as well as agonists of interleukin-6 receptor signaling. Molecular Brain. 2011;4:2.

[72] Galat A, Gross G, Drevet P, Sato A, Menez A. Conserved stuctural determinants in threefingered protein domains. FEBS Journal. 2008;275:3207-25.

[73] Llinas P, Helene Le Du M, Gardsvoll H, Dano K, Ploug M, Gilquin B, et al. Crystal structure of the human urokinase plasminogen activator receptor bound to an antagonist peptide. EMBO J. 2005;24:1655-63.

[74] Ploug M, Ellis V. Structure-function relationships in the receptor for urokinase-type plasminogen activator. Comparison to other members of the Ly- 6 family and snake venom $\alpha$ neurotoxins. FEBS Letters. 1994;349:163-8.

[75] Wilburn DB, Bowen KE, Doty KA, Arumugam S, Lane AN, Feldhoff PW, et al. Structural insights into the evolution of a sexy protein: novel topology and restricted backbone flexibility in a hypervariable vertebrate pheromone. PLOS ONE. 2014;9:e96975.

[76] Watts RA. Stabilizing Selection on Behavior and Morphology Masks Positive Selection on the Signal in a Salamander Pheromone Signaling Complex. Molecular Biology and Evolution. 2004;21:1032-41.

[77] Smith JJ, Putta S, Zhu W, Pao GM, Verma IM, Hunter T, et al. Genic regions of a large salamander genome contain long introns and novel genes. BMC Genomics. 2009;10:19.

[78] Chen J-M, Cooper DN, Chuzhanova N, Férec C, Patrinos GP. Gene conversion: mechanisms, evolution and human disease. Nature Reviews Genetics. 2007;8:762-75. [79] Doley R, Pahari S, Mackessy SP, Kini RM. Accelerated exchange of exon segments in Viperid three-finger toxin genes (Sistrurus catenatus edwardsii; Desert Massasauga). BMC Evolutionary Biology. 2008;8.

[80] Ghaemmaghami S, Huh W-K, Bower K, Howson RW, Belle A, Dephoure N, et al. Global analysis of protein expression in yeast. Nature. 2003;425:737-41.

[81] Laurent J, Vogel C, Kwon T, Craig SA, Boutz DR, Huse HK, et al. Protein abundances are more conserved than mRNA abundances across diverse taxa. Proteomics. 2010;10:4209-12.

[82] Li J, Bickel PJ, Biggin MD. System wide analyses have underestimated protein abundances and the importance of transcription in mammals. PeerJ. 2014;2:e270.

[83] Li JJ, Biggin MD. Statistics requantitates the central dogma. Science. 2015;347:1066-7.

[84] Wang Z, Gerstein M, Snyder M. RNA-Seq: a revolutionary tool for transcriptomics. Nature reviews Genetics. 2009;10:57-63.

[85] Ingolia NT. Ribosome profiling: new views of translation, from single codons to genome scale. Nat Rev Genet. 2014;15:205-13.

[86] MacLean B, Tomazela DM, Abbatiello SE, Zhang S, Whiteaker JR, Paulovich AG, et al. Effect of Collision Energy Optimization on the Measurement of Peptides by Selected Reaction Monitoring (SRM) Mass Spectrometry. Analytical chemistry. 2010;82:10116-24.

[87] Kondrashov FA, Kondrashov AS. Role of selection in fixation of gene duplications. Journal of Theoretical Biology. 2006;239:141-51. 
[88] Francino MP. An adaptive radiation model for the origin of new gene functions. Nature genetics. 2005;37:573-8.

[89] Hendrickson H, Slechta ES, Bergthorsson U, Andersson DI, Roth JR. Amplificationmutagenesis: evidence that "directed" adaptive mutation and general hypermutability result from growth with a selected gene amplification. Proceedings of the National Academy of Sciences. 2002;99:2164-9.

[90] Fry BG, Wüster W, Kini RM, Brusic V, Khan A, Venkataraman D, et al. Molecular evolution and phylogeny of elapid snake venom three-finger toxins. Journal of Molecular Evolution. 2003;57:110-29.

[91] Birtle Z, Goodstadt L, Ponting C. Duplication and positive selection among homininspecific PRAME genes. BMC Genomics. 2005;6:120.

[92] Nei M, Niimura Y, Nozawa M. The evolution of animal chemosensory receptor gene repertoires: roles of chance and necessity. Nature Reviews Genetics. 2008;9:951-63.

[93] Axtner J, Sommer S. Gene duplication, allelic diversity, selection processes and adaptive value of MHC class II DRB genes of the bank vole, Clethrionomys glareolus. Immunogenetics. 2007;59:417-26.

\section{Figures}

Figure 1. Alignment of the six SPF classes. The consensus sequence from each class of SPF was aligned, with the composite consensus sequence shown above and bar height indicating the consensus strength. The black box denotes the signal peptide that is cleaved to form the mature protein.

Figure 2. Comparison of SPF cDNA expression in five male D. ocoee. Approximately $30 \mathrm{SPF}$ cDNA clones were sequenced from each male and the relative expression of each SPF class within the male visualized by pie chart. A sixth chart shows the relative expression of each class of SPF based on all 231 SPF sequences from these five males and prior cDNA libraries. The class I sequence SPF I-01 was identified in every male sampled and constituted $\sim 30 \%$ of all transcripts. The term "hybrid" refers to transcripts that had sections matching two or more different SPF classes which cannot be explained by alternative splicing. 
Figure 3. RP-HPLC chromatogram of D. ocoee whole pheromone extract. Separation of $D$. ocoee pheromone extract using a reverse phase (RP) HPLC, with a 0-70\% ACN gradient at $1 \%$ $\mathrm{ACN} / \mathrm{min}$. A single isoform of SPF (labeled) composed $\sim 30 \%$ of the total pheromone mixture.

Figure 4. Alignment of SPF with members of the TFP superfamily. The SPF TFP-like domains (top) were aligned with members of the TFP superfamily (bottom). Sequences were truncated such that only the TFP domains were included. Cysteine residues are highlighted in black. The four highly conserved TFP disulfide bonds (B1, B2, B3, B4) and an additional bond found within some members (B1A) are shown above the TFP alignment. The SPF disulfide bonding pattern is indicated for both domain 1 and domain 2 (above and below the SPF alignment, respectively).

Figure 5. SPF I-01 gene structure. Exons are drawn to scale, with black coloring representing the 5' and 3' UTRs, light gray representing the signal peptide, and dark gray for the mature protein.

Figure 6. Glucagon and VIP-like proteins. (A) Full length translations of three mental gland glucagon-like proteins (mgGLP1-3) and six VIP-like proteins (VLP1-6). The black boxes denote the signal peptides, with putative cleavage sites shaded in gray and the predicted processed peptides underlined. B) Alignment of processed mgGLP and VLP to peptides from other species. Arrows indicate residues that have been implicated in receptor binding and/or activation of biological activity.

Figure 7. Alignment of insulin-like proteins. Three insulin-like proteins (ILP1-3) were aligned to insulin from $D$. ocoee and other species. Shading represents conservation with the D. ocoee 
insulin sequence. Regions corresponding to the signal peptide, A chain, B chain and C peptide are denoted.

Figure 8. Relaxin-like protein sequences. Alignment of the 4 relaxin-like protein (RLP) sequences are shown, with putative cleavage sites indicated by gray shading. The signal peptide is indicated with a black box. Arrows indicated residues that have been indicated in receptor binding and/or activation of biological activity.

\section{Tables}

Table 1. Categorization of cDNA library sequences. D. ocoee mental gland cDNA sequences grouped into four categories based on BLAST search results. The number of total sequences and the number of contigs are shown.

\begin{tabular}{|l|l|l|l|}
\hline Category & $\begin{array}{l}\text { Number of } \\
\text { Contigs }\end{array}$ & $\begin{array}{l}\text { Number of } \\
\text { Sequences }\end{array}$ & $\begin{array}{l}\text { Percentage of } \\
\text { Total Sequences }\end{array}$ \\
\hline Unknown & 58 & 76 & $32.3 \%$ \\
\hline Hormone-like & 14 & 74 & $31.5 \%$ \\
\hline Cell Maintenance & 29 & 58 & $24.7 \%$ \\
\hline Pheromone/Pheromone- like & 6 & 27 & $11.5 \%$ \\
\hline Total & $\mathbf{1 0 7}$ & $\mathbf{2 3 5}$ & $\mathbf{1 0 0 \%}$ \\
\hline
\end{tabular}




\section{Consensus}

SPE Class I

SPE Class II

SPF Class III

SPE Class IV

SPF Class $V$

SPF Class VI

Consensus

SPE Class I

SPE Class II

SPF Class III

SPE Class IV

SPE Class V

SPF Class VI

Consensus

SPF Class I

SPE Class II

SPF Class III

SPF Class IV

SPF Class V

SPE Class VI
MRAFLTAVIFLVAFTATGNSLDCVHCSSNDGTDCSGEVKTCTDDQTHCQTITSELIQDGDASHQVFKFCG

10

30

40

50

60

70

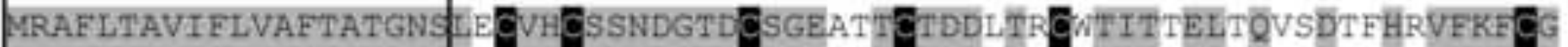
MRAFLTAVIFLVAFTATGNSLDCVHCYSNDGTD CSGEVIT TTDDMTH GRTITSEIMQDGDASHQVEKमCG MRAFLTAVI ELVAFTATGNSIDCVHCYSNDGTDCSGEVI CDNDI TSCLTITSELTQDGAASNQVFKDCA MNAFLTAVI FLVAFTATGNSIDCVH CSSTVGTLCSGEVKI DDEDQTHCOTTTSEI IQDGRASHRVEKम CA MRAFLTAVIBFVAFTATGNS LDVH CSSTVGTD CSGQVKSCPDDQTHCOTITSELIKDGRATRGVFKECA. MRAFLTGVICLVACVATGHSLOCVIGYSFKGKD CSGKAKKGNDYETVGRTSVTQSIENGVTTYHVYKGCS

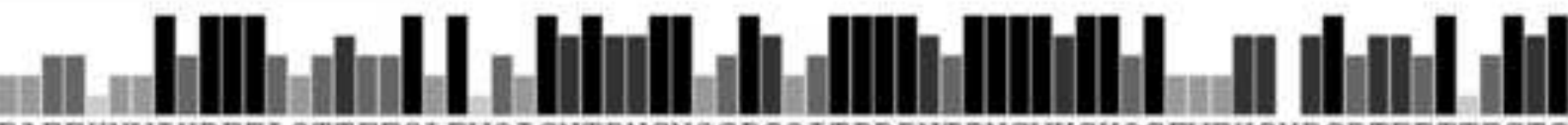

EAEEHNWIHREELSTTFEQLEVQICNTDNCNQGPGQITPRDNTPNGVKCKQCFVEHSXDCDTEETTECTG

$\begin{array}{lllll}80 & 90 & 100 & 110 & 120\end{array}$

140

REKËPTIYREESSTTEEQVESHYCETDNCNQKPGEITPRDNTPNGVKCKHCFEDHSSDGETEETRECTG AAEEHNWIHREELSTTVPQLENQI CNTDN GNQGPGQLTPRDNTPNGVKCKC GYVEHSEVGDTEETTECRG EPGEHSWIHREELSTTVEQLESQY CNTNN GNEGPGQITPRDNRPNGVKC CCEVEHSMD CDTEKTMKCTG EAETENSIHREELLATELQMEVQI CNTDN CNKGPGKITPRDNRPNGVKCKCQYVEHSAD CDSEKTSKCTG EAFAONWIHREELITTEEOLEIQI CNTDN GNQGPGQITPRDNTPNGVKCROCEADKSVD CDTGETRECTG DIEEKDSIYREBSKNSEHQVEVKH CNTDI GNKEPMPLTPRDYTPNGVI EKD GYKNHTLDCETEETVECNG

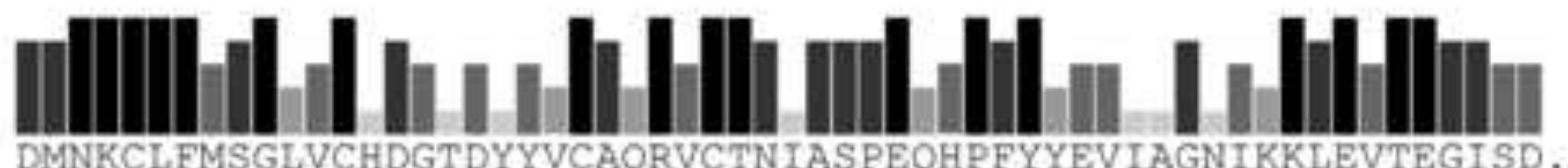

150

160

170

180

190

DMNK CLFMSGLI GYNGEDYY GTHRI ETNIASPEEHPEYNDFISGDIKKLEVTEGISD. DMNKCLFMSGLV CNDGTDYYVCAORV CINLASPEQHPEYEBVTAGNIOKIEITEGISDA. DMNKCLEMSGLVCHDGTDEYVCAQRV CWNIASPEQHPFYYEVYTGYIKKLEVTEGIRYE. DMNKCEFISGFVCDD--D-DVCAQRV CINMASPEQYPFYYEVIAGNIHKLEVTEGISDV. DMNKCLFMSGFV CHDGAN-YNCAHRV CINMASPEKY PEYYEVGDGTVKKLEVTEGISD. ELNKCLFLAGQIGIDEDSWENCAYRH GIDVQEVEMHPYYSALPNELVOKLEITERL. 
A
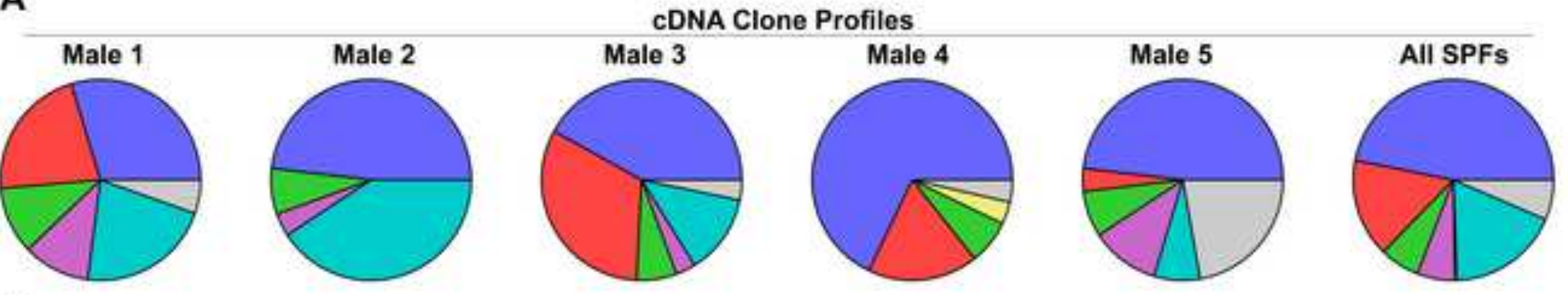

B

\section{MS Profiles}
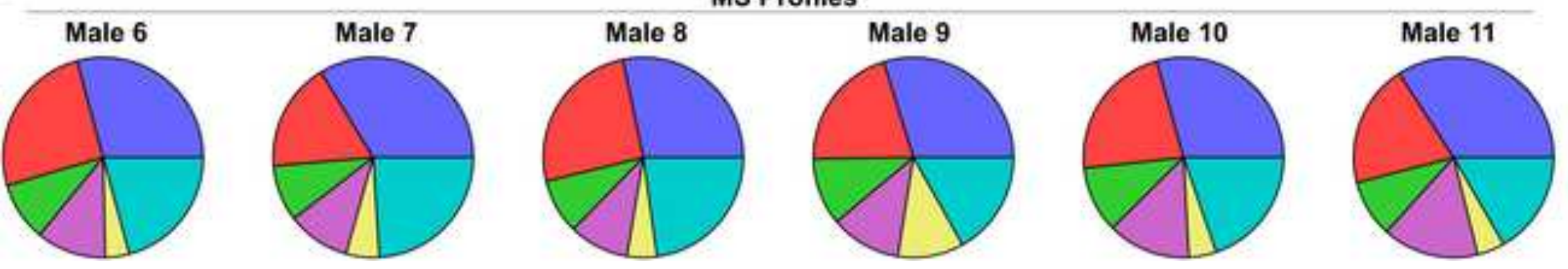

$\square$ Class 1

$\square$ Class II

$\square$ Class III $\square$ Class IV $\square$ Class V $\square$ Class VI $\square$ Hybrid 


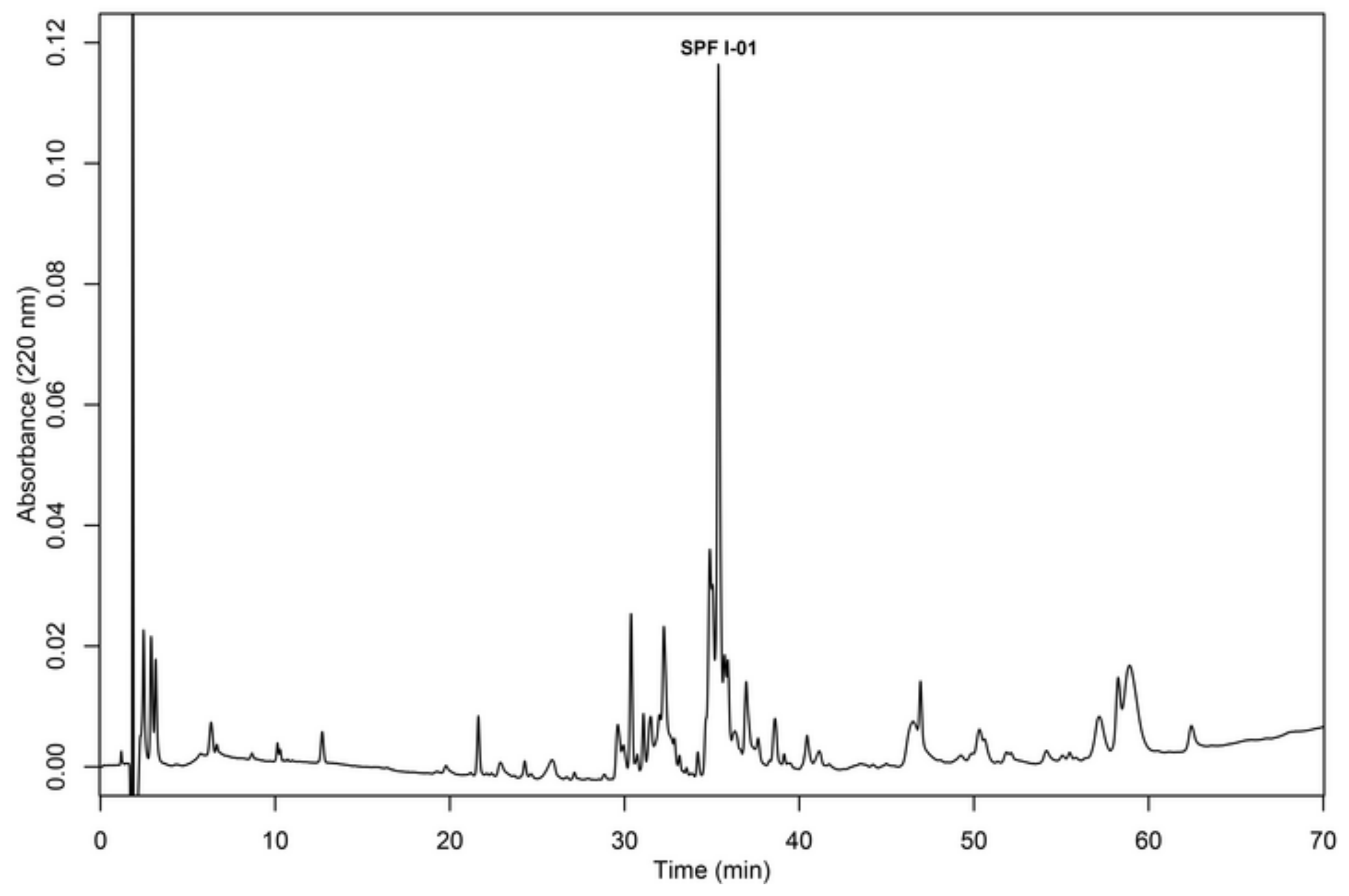




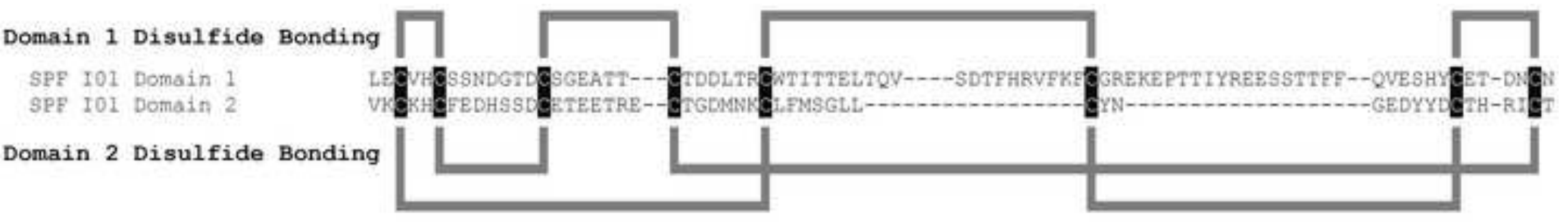

\title{
TFP Disulfide Bonding
}

\author{
UPAR Domain 1 \\ UPAR Domain 2 \\ UPAR Domain 3 \\ CDS9 (Bumian) \\ PLI 〈P. elegans) \\ LY6-Like (Mus musculus) \\ Xenopus CD59-11ke \\ Xenoxin 1 Precursor \\ Fasciculin 1 \\ Fasciculin 2 \\ Naja nigricollis Toxin A \\ Erabutoxin B \\ Proa 1
}

B1

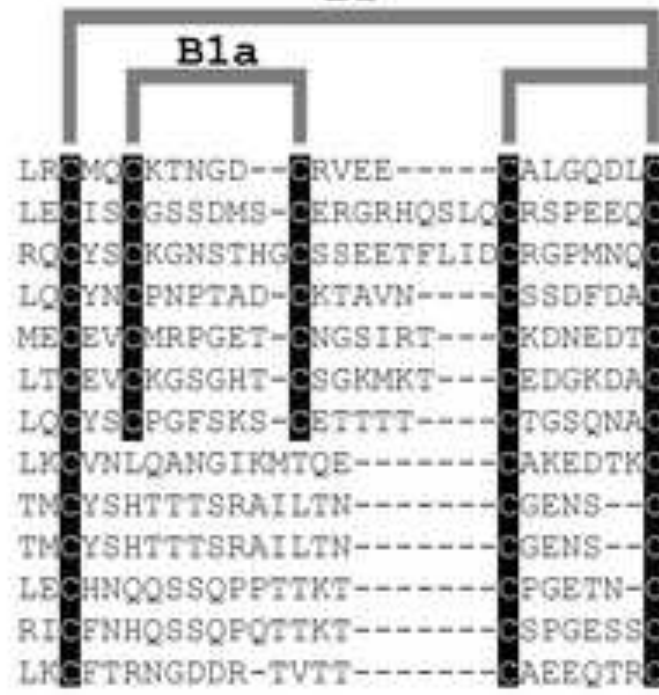

B3

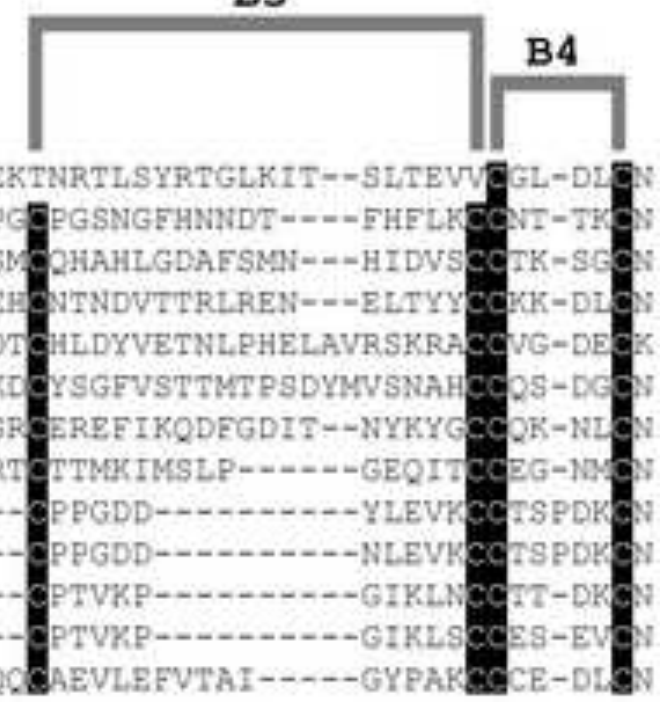

B2

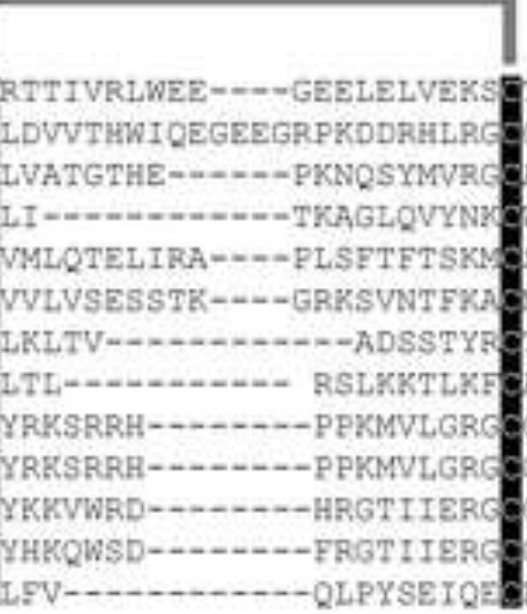

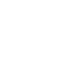




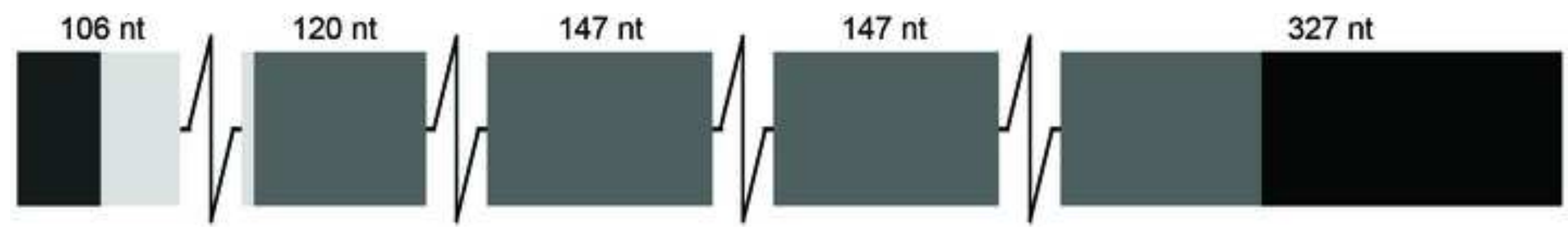


A

mgGLPI MOHKIGVLELFCFTLLYLRAQASLIPGIDSAMGVSVRHAE EKRHSOGTETSDYSKYLDRKMAYSEIDSLMKMTSSGKKKI SPRASEGEKTNLNKHNSK

mgGLP2 WQHKIGVLFLECETLLYLRARASLIPGIDSAMGVSVRHAE EKRHSOGTETSDYSKYLDRKMAYSEIDSLMKMSSSGKKKI, SPRASFGEKINLNKHNSK

mgGLP3 WOQKSGVLELGEFTLLELWAQASPVPGADAGSSSVSRPKA EFKRHADGTETSDVASYLERQTVKAFIKFLOEESENKKEI LQRVT DWMERS LKRGE LAPIEEVNI LDNTQ

\section{Glucagon}

mgGLP1 mgGLP2

D. ocoee

D. rerio

$x$. laevis

G. gallus

H. sapiens

\section{GLP1}

mgGLP3

D. ocoee

D. rerio

$\mathrm{X}$. Laevis

G. gallus

H. sapiens

DEEILSVKRHADALETAGYSRFRYNKAMMKYLKSTUTRPP SIVSKKDVEPTGITHDPFIFPGYRTHKY

108

VLP3 MOHKSSEPELLCFEILSLLYLOAOALPALERYAMSENAL NEE IT PVKRUSDAEETDGYSROLTKAKLEKYULSDVLGAKI RLP

VLP4 MOHKSSEPEICEFILSILYLQAQALLALGTYSAMSENAL NEEI TPVKRHSDAEETDGYTRQLAKEQLEKYLSDVLGAKI BL.P

VLP5 MQOMSIYLFLLGE IBLYLWARASPTSEEDSAWSNNYLEEE MPTIKRHVDGHETHSYSRYRNKMATLKYLKSVHPGTKSEV KKPKA

VLP6 BQCMSIYLELLGSISLYLWAQASPTSEEDSAWSNNVLEEE MPTIKRHVDGLETHSYSRYRNKMAILKYLKSVLPGTKSNN VLEEEMPTIRRHVDGLFTHSYSRYRNKMALLKYLKSVLPG TKSEVKKPKA

\section{VIP}

VLPI

VLP2.

VLP3

VLP4

VLP5

VLP6

D. rerio

$\mathrm{X}$. Laevis

G. gallus

H. saplens

\section{W WWW}

HSOGTETSDYSKYLDRKMAYSF̈IDSLMKMTSSG 33

HSQGTFTSDYSKYLDRKMAYSFIDSLMKMSSSG 33

HSQGTEISDYSKYLDNRRAQDEIOWLMST 29

HSEGTFSNDYSKYLETRRAODEWOWLMNA 29

HSOGTETSDYSKYLDSRRAQDEVQWLMNTI 29

HSOGTETSDYSKYLDSRRAQDFVOWLMST

HSOGTETSDXSKYLDSRRAQDEVQWLMNT 29

HADGTFTSDVASYLERQTIVKAFTKELOEESEN 32

HADGTLTSDISSYLEKQATKEFIAWLVNGRG 31

HAEGTYTSDVSSYLODQAAOSFVAWIKSGOP 31

HAEGTYTSDVSSYLODQAAQSEVAWLKSGQP 31

HAEGTYTSDITSYLEGQAAKEE IAWLVNGRG 31

HAEGTFTSDVSSYLEGQAAKEFIAWLVKGRG 31

HADALFTAGYSKIRYNAAVRKYFESVLTRPKSIVP 35 HADALFTAGYSRERYNKAMMKYLKSIVTRPESIVS HSDAEFTDGYSROLIKEKLEKYLSDVLGAKIRLP HSDAEETDGYTRQLAKEQLEKYLSDVLGAKIRLP 34 HVDGLFTHSYSRYRNKMATLKYLKSVL PGTKSEV HVDGLFTHSYSRYRNKMAA ILKYLKSVLPGTKSNNVLEEEMPTI 43 HSDAI FTDNYSRERKQMAVKKYLNSVLT. HSDAVFTDNYSRFRKQMAVKRYLNSVLT HSDAVFTDNYSRERKOMAVKKYLNSVLT 28 HSDAVFTDNYTRLRKONAVKKYLNSILN 28 


Signal Peptide

10 20

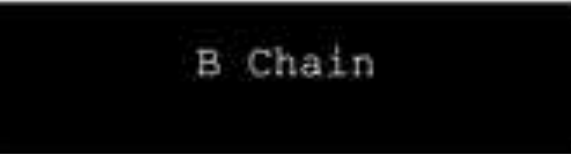

40

50

C Peptide

50 00 


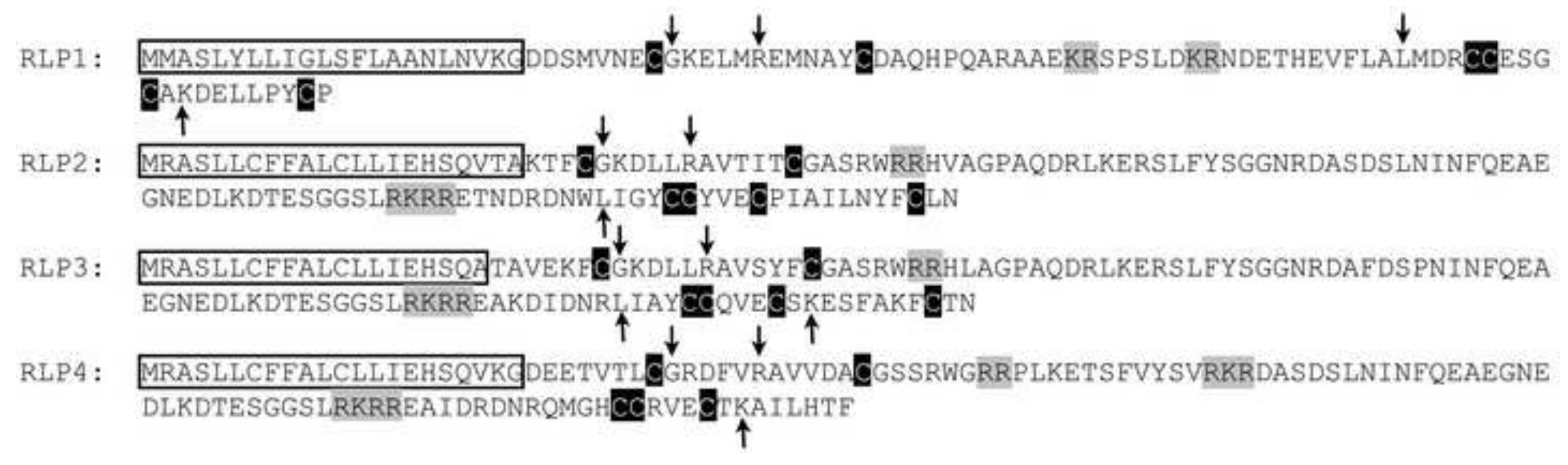

